\title{
Clinical Efficacy of Rifampicin for Treatment of Canine Pyoderma
}

\author{
S. SENTÜRK ${ }^{1}$, E. ÖZEL ${ }^{2}$, A. SEN ${ }^{2}$ \\ ${ }^{1}$ Department of Internal Medicine, Veterinary Faculty, Uludag University, Turkey \\ 2 Department of Microbiology, Veterinary Faculty, Uludag University, Turkey \\ Received January 8, 2004 \\ Accepted March 3, 2005
}

\begin{abstract}
Sentürk S., E. Özel, A. Sen: Clinical Efficacy of Rifampicin for Treatment of Canine Pyoderma. Acta Vet. Brno 2005, 74: 117-122.

In this study, the efficacy and field safety of rifampicin were evaluated in dogs with pyoderma. Clinical diagnoses of canine pyoderma were supported by bacteriologic cultures. 20 dogs with pyoderma were treated with rifampicin at a dose of $5 \mathrm{mg} \cdot \mathrm{kg}^{-1}$ once daily for 10 days. Staphylococcus intermedius (40\%) was isolated as the predominant pathogen. Serum GGT, ALT, urea, creatinine levels were assessed both before and after treatment for hepatic and renal effects of rifampicin. However, these parameters after treatment were not found to be statistically different compared with the values before treatment. While treatment was clinically successful in 18/20 $(90 \%)$ dogs with pyoderma, poor improvement was noted in $2 / 20(10 \%)$ dogs. Rifampicin was safe and effective for the treatment of canine pyoderma at the dosage used in this study.
\end{abstract}

Staphylococcus intermedius, Dog, urea, Rifamycin

Pyoderma is one of the most common causes and the most persistent of canine skin diseases worldwide (Ihrke 1987; Hill and Moriello 1994). Lesions may be quite superficial and affect only the epidermis or may involve deeper structures in the dermis or subcutaneous tissue. The primary pathogen of superficial pyoderma cases involve Staphylococcus intermedius, a member of the normal flora in most dogs (Noble and Kent 1992; Hill and Moriello 1994; Scott et al. 1994; Ihrke 1996; Scott et al. 1998). Also $S$. aureus is the causative organism (Harvey et al. 1996; Paradis et al. 2001). However, other causative organisms such as Proteus spp., Pseudomonas spp., E. coli, Actinomyces spp., Actinobacillus spp., Fusobacterium spp., and Mycobacterium spp. can occur deep pyoderma (Debouer 1995; Scott et al. 1995; Paradis et al. 2001). Deep pyodermas do not occur spontaneously in normal dogs. Deep skin infections are generally the continuation of a superficial infection (Ihrke 1987; Scott et al. 1995; Papich 1995).

In therapy of canine pyoderma, the selected antibiotic should have good skin penetration and be active against Staphylococcus spp. (especially, S. intermedius). In addition, the antibiotic selected depends on the type of infection, efficacy, and safety profile. The antibiotic chosen ideally should not be inactivated by penicillinase (Ihrke 1987; Hill and Moriello 1994; DeBouer 1995; Papich 1995; White 1996; Littlewood et al. 1999).

Rifampicin is essential for short-course chemotherapy in patients with active tuberculosis (Thornsberry et al.1983; Molavi 1990). Rifampicin in combination with doxycycline has been recommended in treatment of brucellosis in dogs (Mateu-de-Antonio and Martin 1995). Rifampicin has the unusual advantage of being able to penetrate tissues extremely well, even going intracellularly (Lobo and Mandell 1972; Bergan 1981; Molavi 1990; Frank 1990). This unique ability to penetrate tissues and cells so well, along with the usual sensitivity of susceptible staphylococci to small concentration of the drug, makes rifampicin an effective antibiotic. Rifampicin may be chosen in deep pyoderma and

Address for correspondence:

S. Sentürk

Department of Internal Medicine

Veterinary Faculty

Uludag University

16190 Bursa - TURKEY

Phone: 00902242347655

Fax: 00902242346395

E-mail: sezsen8@yahoo.com

http://www.vfu.cz/acta-vet/actavet.htm 
recurrent or resistant superficial pyoderma (Bergan 1981; Ackerman 1987; Frank 1990). However, this drug may cause hepatotoxicity, and acute renal failure (Thorns bery et al. 1983; Molavi 1990; Frank 1990). Therefore, it should be used with caution in patients with preexisting hepatic and renal dysfunction.

The aim of this study was to evaluate the efficacy of rifampicin in the treatment of naturally occurring pyoderma in dogs.

\section{Materials and Methods}

In total, 20 adult dogs of several breeds (6 English Pointer, 9 German Shepherds, 2 Anatolian Shepherds and 3 Labrador retrievers), sex (14 neutered males, 6 neutered females) were enrolled in the study. Ages ranged from 2 to 8 years. Body weights ranged from 15.4 to $42.5 \mathrm{~kg}$. At the pretreatment, a physical examination (such as body temperature, pulse, respiratory rate) of all dogs was performed. Dogs suspected from an underlying disease such as hyperadrenocorticism, hypothyroidism and diabetes mellitus that might affect their ability to respond to antibiotics were excluded from the study. In history, it was noted that some of the dogs had been treated only with parenteral antibiotics ( 2 dogs with enrofloxacin, 2 dogs with amoxicillin + clavulanic acid, 2 dogs with ampicillin, $1 \mathrm{dog}$ with trimethoprim/sulfadiazine, and $1 \mathrm{dog}$ with cefazolin) within the previous month. In addition, it was reported that corticosteroid ( 6 dogs with prednisolone) and antibiotics ( 3 dogs with amoxicillin, 3 dog with cefozolin), or antihistamines (4 dogs with chlorpheniramine, 2 dogs with hydroxyzine) had been applied. Specific clinical lesions indicative of pyoderma were documented. Skin lesions were characterized with regard to clinical sings, location and extent. Diagnosis of pyoderma was based on history, physical examination and bacterial culture. In the present study, the classification of the pyoderma as superficial and deep was based on the clinical impression of the investigators. In all cases, skin scrapings were obtained and evaluated for abnormalities. A sample for bacterial culture (such as pustules, exudates) was obtained from the side of infection. Lesions were not disinfected prior obtaining sample. For isolation procedures, dry, cotton tipped swabs were used. The swabs were placed into Stuarts transport medium. Samples were inoculated onto Blood Agar Base (No.: 2, Oxoid ${ }^{\circledR}$ CM-271) MacConkey Agar within $24 \mathrm{~h}$ of sampling. The plates were incubated overnight in air at $37{ }^{\circ} \mathrm{C}$. Bacteriological identification were carried out and evaluated based on the methodological guide (Koneman et al. 1992).

Blood samples were taken from each dog before treatment, and at the end of treatment to evaluate serum urea, serum creatinine, serum gamma glutamyl transferase (GGT), serum alanine amino transferase (ALT). Serum urea, creatinine, GGT, ALT (Spinreact ${ }^{\circledR}$, Reactivos Spinreact, S.A., Gerona, Span) values were determined by spectrophotometer (Labospec ${ }^{\circledR}$, Pharmacia Inc., England).

Rifampicin (Rifadin ${ }^{\mathbb{R}}$, Aventis Pharma Inc., Istanbul, Turkey) was administered by the oral route to each dog at a dose of $5 \mathrm{mg} \cdot \mathrm{kg}^{-1}$ of body weight, twice a day for $10 \mathrm{~d}$. A post-treatment evaluation was performed at end of 10 $\mathrm{d}$ to evaluate clinical response. The results of treatment were categorized as clinical success, improvement or failure. Clinical success was defined by resolution of all active lesions; clinical failure was defined as the presence of active lesions, which were unchanged or worse. Clinical response of dogs with pyoderma was observed during 1 month after treatment.

Assessment of efficacy was based primarily on clinical resolution of lesions in each dog. In order to detect the significance of the difference of the parametrical values (GGT, GPT, Urea, Creatinine), student $t$-test and tukey test were used.

\section{Results}

A general dermatological examination was carried out in all animals, both before and after the treatment. In pretreatment evaluation, lesions were seen generally on the face, groin, axilla, abdomen, back, skin folds, muzzle, and dorsum of thorax. Skin lesions generally included patchy, crusted papules, erythema, localize or generalize pustules, alopecia, seborrhea, excoriations, erosions, epidermal collarettes, discrete nodules, alopecia, hemorrhagic bullae, cellulites, irregular ulcers, fistulae. Eighteen dogs (90\%) had superficial pyoderma and 2 dogs $(10 \%)$ had a deep pyoderma (Table 1$)$.

Skin scraping was negative for demodicosis and scabies. Bacteriological cultures were performed in 20 dogs. Species of bacteria were identified in all dogs. Isolated organisms were Staphylococcus intermedius (45\%), Staphylococcus aureus (15\%), Staphylococcus epidermidis (30\%), and Proteus spp. (10\%).

Treatment was considered successful in 18/20 (90\%) dogs with pyoderma. No recurrence was observed during the 1-month follow - the rifampicin therapy. It was observed that the effectiveness of rifampicin was poor in 2 of $20(10 \%)$ dogs with pyoderma.

Before and after treatment, serum GGT, ALT, urea and creatinin concentrations were 
evaluated. It was determined that there were no statistically differences in these values (Table 2). In all dogs given rifampicin was seen that the urine had orange color. Local or general side effects of rifampicin were not observed in any dog.

Table 2. Results of biochemical parameters before treatment and 10 days after treatment

\begin{tabular}{|l|c|c|}
\hline Parameters & $\begin{array}{c}0 . \text { day } \\
(\text { Mean } \pm \text { SE) }\end{array}$ & $\begin{array}{c}\text { 10.days } \\
(\text { Mean } \pm \text { SE) }\end{array}$ \\
\hline Urea $\left(\mathrm{mmol} \cdot \mathrm{l}^{-1}\right)$ & $4.7 \pm 0.3$ & $5.3 \pm 0.2$ \\
\hline Creatinin $\left(\mu \mathrm{mol} \cdot \mathrm{l}^{-1}\right)$ & $79.5 \pm 7$ & $97.2 \pm 7$ \\
\hline GGT $\left(\mathrm{UI} \cdot \mathrm{l}^{-1}\right)$ & $7.8 \pm 0.4$ & $10.1 \pm 0.7$ \\
\hline ALT $\left(\mathrm{UI} \cdot \mathrm{l}^{-1}\right)$ & $22.2 \pm 1.2$ & $26.6 \pm 0.9$ \\
\hline
\end{tabular}

\section{Discussion}

Pyoderma is one of the most common canine skin diseases (Ihrke 1987; Hill and Moreillo 1994; Ihrhe 1996; Scott et al. 1995). It is defined as a pyogenic or pusproducing bacterial infection of the skin. Staphylococcus intermedius, a gram-positive coagulase-positive bacterium, is the most common infectious agent cultured in canine pyoderma (Noble and Kent 1992; Harvey et al. 1993; Hill and Moreillo 1994; Harvey 1996; Littlew ood et al. 1999). Occasionally, S. aureus is the causative organism. Gram-negative organisms are usually secondary invaders in dogs with pyoderma (Ihrke 1987; Hill and Moriello 1994). However, gram negative organisms such as Proteus spp., Pseudomonas spp. and E. coli may be involved in deep pyoderma (Hill and Moriello 1994; Paradis et al. 2001). In this study, the most commonly isolated organism was $S$. intermedius ( $9 / 20 \mathrm{dogs}, 45 \%)$, followed by $S$. epidermidis $(6 / 20 \mathrm{dogs}, 30 \%)$, S. aureus $(3 / 20$ dogs, $15 \%)$ and Proteus spp. (2/20 dogs, 10\%).

The choice of antibacterial available for administration to dogs with pyoderma has expanded considerably in recent years (Harvey et al. 1993; Sc ott et al. 1993; Sc ott et al. 1994; Harvey 1996; Ihrke 1996; White 1996; Lloyd et al. 1997; Scott et al. 1998; Carlotti et al. 1999; Littlew ood et al. 1999; Paradis et al. 2001). However, no single antibacterial is ideal for all types of canine pyoderma. The basic principles of effective systemic antibacterial therapy include choice of the proper antibacterial, establishment of an effective dosage, and long enough maintenance of therapy to ensure a cure rather than a simply transient remission. Indeed, the ideal antibacterial has a narrow spectrum of activity but is effective against $S$. intermedius. The selected antibacterial should achieve good concentration in the skin. Also, the selected antibacterial ideally should not be inactivated by penicillinase (Ihrke 1987; Hill and Moriello 1994; Scott et al. 1995; Debouer 1995; White 1996; Whittem and Gaon 1998; Paradis et al. 2001). Rifampicin is the semi-synthetic derivative of rifamycin B, a macrocyclic compound produced by Streptomyces mediterranei. It inhibits the bacterial RNA polymerase in a completely specific way (Fonseca 1988; Molavi 1990; Plumb 1999). Microorganisms that have been reached by its specter show sensitivity to high concentrations of this antibiotic. Therefore, the blood level obtained may have bactericidal activity (Fonseca 1988). Rifampicin is metabolized in the liver to a deacetylated form which also has antibacterial activity. Both this metabolite and unchanged drug are excreted primarily in the bile, but up to $30 \%$ may be excreted in the urine (Plumb 1999).

Rifampicin is an antibacterial that is activity against many gram positive and some gram negative aerobic bacteria as well as facultative anaerobic organisms (Wils on et al. 1988; Frank 1990; Kohn et al. 1993; Barragry 1994). Especially, rifampicin is highly active against Mycobacterium tuberculosis and Mycobacterium leprae. In addition to 
Table 1. Signalment in dogs, skin lesions and the classification of the pyoderma

\begin{tabular}{|c|c|c|c|c|c|}
\hline Cases & Breed & $\begin{array}{c}\text { Age } \\
\text { (years) }\end{array}$ & Sex & Skin lesions & $\begin{array}{l}\text { The classification of the } \\
\text { pyoderma }\end{array}$ \\
\hline 1 & English pointer & 2 & Male & $\begin{array}{l}\text { Erythema, suppuration, } \\
\text { crusted papules }\end{array}$ & Superficial pyoderma \\
\hline 2 & English pointer & 2 & Male & $\begin{array}{l}\text { Papulo-pustules, } \\
\text { erythema, suppuration, } \\
\text { epidermal collarettes }\end{array}$ & Superficial pyoderma \\
\hline 3 & English pointer & 3 & Female & $\begin{array}{l}\text { Epidermal collarettes, } \\
\text { crusted papules, } \\
\text { suppuration, erythema }\end{array}$ & Superficial pyoderma \\
\hline 4 & English pointer & 2 & Male & $\begin{array}{l}\text { Erythema, epidermal } \\
\text { collarettes, crusted } \\
\text { papules, suppuration, }\end{array}$ & Superficial pyoderma \\
\hline 5 & English pointer & 4 & Female & $\begin{array}{l}\text { Erythema, crusted papules, } \\
\text { suppuration, pustules }\end{array}$ & Superficial pyoderma \\
\hline 6 & English pointer & 5 & Male & $\begin{array}{l}\text { Erythema, epidermal } \\
\text { collarettes, crusted } \\
\text { papules, suppuration }\end{array}$ & Superficial pyoderma \\
\hline 7 & German Shepherd & 2 & Male & $\begin{array}{l}\text { Erythema, epidermal } \\
\text { collarettes, crusted } \\
\text { papules, suppuration }\end{array}$ & Superficial pyoderma \\
\hline 8 & German Shepherd & 3 & Female & $\begin{array}{l}\text { Epidermal collarettes, } \\
\text { crusts, pustules, erythema }\end{array}$ & Superficial pyoderma \\
\hline 9 & German Shepherd & 3 & Male & $\begin{array}{l}\text { Papulo-pustules, } \\
\text { erythema, suppuration, } \\
\text { epidermal collarettes }\end{array}$ & Superficial pyoderma \\
\hline 10 & German Shepherd & 4 & Male & $\begin{array}{l}\text { Erythema, crusted papules, } \\
\text { suppuration, pustules }\end{array}$ & Superficial pyoderma \\
\hline 11 & German Shepherd & 2 & Male & $\begin{array}{l}\text { Erythema, exudation, } \\
\text { suppuration, follicular } \\
\text { pustules }\end{array}$ & Superficial pyoderma \\
\hline 12 & German Shepherd & 3 & Male & $\begin{array}{l}\text { Fistulae, erythema, } \\
\text { exudation, pustules }\end{array}$ & Superficial pyoderma \\
\hline 13 & German Shepherd & 2 & Female & $\begin{array}{l}\text { Erythema, exudation, } \\
\text { cellulitis, crusted papules }\end{array}$ & Deep pyoderma \\
\hline 14 & German Shepherd & 6 & Male & $\begin{array}{l}\text { Hemorrhagic bullae, } \\
\text { irregular ulcers, } \\
\text { fistulae, cellulitis }\end{array}$ & Deep pyoderma \\
\hline 15 & German Shepherd & 2 & Male & $\begin{array}{l}\text { Erythema, epidermal } \\
\text { collarettes, suppuration, } \\
\text { crusted papul }\end{array}$ & Superficial pyoderma \\
\hline 16 & Anatolian Shepherd & 3 & Female & $\begin{array}{l}\text { Erythema, crusted papules, } \\
\text { suppuration, pustules }\end{array}$ & Superficial pyoderma \\
\hline 17 & Anatolian Shepherd & 4 & Male & $\begin{array}{l}\text { Erythema, epidermal } \\
\text { collarettes, crusted papules, } \\
\text { suppuration }\end{array}$ & Superficial pyoderma \\
\hline 18 & Labrador Retriever & 2 & Female & $\begin{array}{l}\text { Erythema, suppuration,. } \\
\text { pustules }\end{array}$ & Superficial pyoderma \\
\hline 19 & Labrador Retriever & 3 & Male & $\begin{array}{l}\text { Epidermal collarettes, } \\
\text { crusted papules, } \\
\text { suppuration, erythema }\end{array}$ & Superficial pyoderma \\
\hline 20 & Labrador Retriever & 8 & Male & $\begin{array}{l}\text { Epidermal collarettes, } \\
\text { crusted papules, } \\
\text { suppuration, erythema }\end{array}$ & Superficial pyoderma \\
\hline
\end{tabular}


mycobacteria, it is extremely active against $S$. aureus and coagulase-negative staphylococci, methicillin resistant strains, and is also effective against nonenterococcal Streptococcus species and Listeria monocytogenes (Molavi 1990). However, most gram-negative bacteria should be considered resistant (Thorn sberry 1983; Barragry 1994). Rifampicin readily penetrates most tissues, especially the skin, and it can penetrate phagocytic cells to kill susceptible intracellular bacteria (Kohn et al. 1993; Barragry 1994; Wilson et al. 1988; Lobo and Mandell 1972). Based on these characteristics, rifampicin may be used especially active in the treatment of staphylococcal infections and in the eradication of pathogens located in difficult to reach target areas. In our study, treatment of 18 (90\%) dogs with pyoderma was classified as successful after $10 \mathrm{~d}$. Rifampicin showed an excellent response in these dogs. However, treatment was considered as failure in two $(10 \%)$ dogs after $10 \mathrm{~d}$. In these two dogs, Proteus spp. was isolated. Wils on et al. (1988) were reported that Proteus spp. was to be resistant against rifampicin. Therefore, rifampicin therapy may be not effect in these dogs with pyoderma.

Duration of treatment must be long enough (a few weeks to several months depending of extension and depth of lesions). As a rule, if pyoderma reoccurs within 2-3 weeks after completing the antibiotic treatment, it is probable that the duration of treatment was too short. On the other hand, if recurrence develops more than several weeks after the antibiotic treatment is concluded, it is the more likely a true recurrence of bacterial pyoderma (Paradis et al. 2001). In the present study, duration of treatment was designed for $10 \mathrm{~d}$. It can be thought that this duration is short. However, the pyoderma resolved completely in $90 \%$ of cases. In addition, no recurrence was observed within 1 month following rifampicin therapy. Response to therapy was poor in $2(10 \%)$ of the dogs, which had deep pyoderma. Duration of treatment might be too short for these dogs.

The selected antibacterial for pyoderma should have minimal adverse effects (Ihrke 1987; Hill and Moriello 1994; Papich 1995). The adverse effects of rifampicin occasionally include rashes, nephritis, and hepatitis (Frank 1990; Molavi 1990; Barragry 1994; Mae et al. 1998; Plumb 1999). There is very little information about the adverse effects of rifampicin in dogs. However, there is anecdotal information warning that up to $20 \%$ of dogs receiving $5-10 \mathrm{mg}$ per $\mathrm{kg}$ of body weight a day will develop increased in hepatic enzymes concentrations that may lead to clinical hepatitis (Frank 1990). In the present study determined that hepatic enzymes increased in minimal levels (Table 1). Rifampicin imparts a harmless orange color to urine, tears (Frank 1990; Molavi 1990). It was observed that color of urine was orange in all dogs that were given rifampicin.

Resistance to rifampicin can develop quickly; therefore, it is most often used combination with other antimicrobials (Thornsberry et al. 1983). Cross-resistance to other antibiotics or transfer of resistance to other local microorganisms has not been reported (F rank 1990).

In conclusion, the results of this study suggest that rifampicin is effective in the treatment of naturally occurring staphylococcal pyoderma in dogs under field conditions. However, it must be observed that its use should be restricted to non-responders to standard eradication therapy for pyoderma in order to avoid the development of rifampicin resistance in mycobacteria.

\section{Klinický účinek rifampicinu pro léčbu pyodermie psů}

$\mathrm{V}$ této studii byla vyhodnocena účinnost a (praktická) bezpečnost rimfampicinu u psů s pyodermií. Klinická diagnóza byla stanovena s využitím bakteriologické kultivace. Dvacet psủ s pyodermií bylo léčeno dávkou $5 \mathrm{mg} \cdot \mathrm{kg}^{-1}$ rimfampicinu jednou denně po 10 dní. Mezi izolovanými patogeny převládal Staphylococcus intermedius (40\%). Pro zjištění vlivu rimfampicinu na játra a ledviny byly před a po léčbě měřeny hodnoty sérového GGT, ALT, urey a kreatininu. Při srovnání hodnot zjištěných před a po vyšetření však nebyly zjištěny 
statisticky významné rozdíly. Zatímco léčba byla klinicky úspěšná u 18/20 (90\%) psů s pyodermií, slabý účinek byl zaznamenán u 2/20 (10\%) psů. Rimfampicin v dávce použité v této studii byl bezpečný a efektivní pro léčbu pyodermie u psů.

\section{References}

ACKERMAN, L 1987: Cutaneous bacterial granuloma (botryomycosis) in five dogs: treatment with rifampin. Mod Vet Pract 68: 404-409

BARRAGRY, TB 1994: Veterinary Drug Therapy. Lea and Febiger, Philadelphia, PA, 488 p.

BERGAN, T 1981: Pharmocokinetics of tissue penetration of antibiotics. Rev Infect Dis 3: 45-66

CARLOTTI, DN, GUAGUERE, E, PIN, D, JASMIN, P, THOMAS, E, GUIRAL, V 1999: Therapy of difficult cases of canine pyoderma with marbofloxacin: a report of 39 dogs. J Small Anim Pract 40: 265-270

DEBOUER, DJ 1995: Management of chronic and recurrent pyoderma in the dog. In: BONAGURA, JD (ed.): Kirk's Current Veterinary Therapy XII: Small Animal Practice, WB SAUNDERS, Philadelphia, p. 611-617

FONSECA, AL 1988: Antibióticos na Clínica Diária. 3rd ed., São Paulo, Epume Edit. Public Médicas Ltda.

FRANK, LA 1990: Clinical pharmacology of rifampin. J Am Vet Med Assoc 197: 114-117

HARVEY, RG 1996: Tylosin in the treatment of canine superficial pyoderma. Vet Rec 139: 185-187

HARVEY, RG, NOBLE, WC, FURGUSON, EA 1993: A comparison of lincomycin hydrochloride in the treatment of superficial pyoderma in dogs. Vet Rec 132: 351-353

HILL, PB, MORIELLO, KA 1994: Canine pyoderma. J Amer Vet Med Assoc 204: 334-340

IHRKE, PJ 1987: An overview of bacterial skin disease in the dog. Br Vet J 433: 112-118

IHRKE, PJ 1996: Experience with enrofloxacin in small animal dermatology. Comp Cont Edu 18: 35-39

KOHN, CW, SAMS, R, KOWALSKE, J, POWERS, J, WALLACE, S 1993: Pharmacokinetics of single intravenous and single and multiple dose oral administration of rifampin in mares. J Vet Pharmacol 16: 119-131

KONEMAN, EW, ALLEN, SD, JONDA, WM, SCHRECKENBERG, PC, WINN, WC 1992: Color atlas and textbook of diagnostic microbiology, Lippincott Company, Philadelphia, pp. 405-446

LITTLEWOOD, JD, LAKHANI, KH, PATERSON, S, WOOD, JL, CHANTER, RN 1999: Clindamycin hydrochloride and clavulanate-amoxycillin in the treatment of canine superficial pyoderma. Vet Rec 144: 662-665

LLOYD, DH, CARLOTTI, DN, KOCH, H, VAN DEN BROEK, AH 1997: Treatment of canine pyoderma with co-amoxyclav - a comparison of two doses rates. Vet Rec 141: 439-441

LOBO, MC, MANDELL, GL 1972: Treatment of experimental staphylococcal infection with rifampin. Antimicrob Agents Chemother 2: 195-200

MAE, T, HOSOE, K, YAMAMOTO, T, HIDAKA, T, OHASHI, T, KLEEMAN, JM, ADAMS, PE 1998: Effect of a new rifamycin derivate, rifalazil, on liver microsomal enzyme induction in rat and dog. Xenobiotica 28: 759-766

MOLAVI, A 1990: Antimicrobials III. In: DiPalma, JR and DiGregoria GJ (Ed): Basic Pharmacology in Medicine. McGraw-Hill Publishing Company, London. pp. 627-628

NOBLE, WC, KENT, LE 1992: Antibiotic resistance in Staphylococcus intermedius isolated from cases of pyoderma in the dog. Vet Dermatol 3: 71-74

PAPICH, MG 1995: Antimicrobial Drugs. In: ETTINGER SJ, FELDMAN EC (Ed): Textbook of Veterinary Internal Medicine- Disease of Dogs and Cats, WB SAUNDERS, Philedelphia, pp. 272-284

PARADIS, M, ABBEY, L, BAKER, B, COYNE, M, HANNIGAN, M, JOFFE, D, PUKAY, B, TRETTIEN, A, WAISGLASS, S, WELLINGTON, J 2001: Evaluation of the clinical efficacy of marbofloxacin (Zeniquin ${ }^{\circledR}$ ) tablets for the treatment of canine pyoderma: an open clinical trail. Vet Dermatol 12: 163-169

PLUMB, DC 1999: Veterinary Drug Handbook, $3^{\text {rd }}$ ed., Iowa State University Pres/Ames, Minnesota, pp. 654-656

SCOTT, DW, BENINGO, KE, MILLER, WH, ROTHSTEIN, E 1998: Efficacy of clindamycin hydrochloride capsules for the treatment of deep pyoderma due to Staphylococcus intermedius infection in dogs. Canadian Vet J 39: 753-756

SCOTT, DW, MILLER, WH, CAYATTE, SM, BAGLADI, MS 1994: Efficacy of tylosin tablets for the treatment of pyoderma due to Staphylococcus intermedius infection in dogs. Canadian Vet J 35: 617-621

SCOTT, DW, MILLER, WH, GRIFFIN, CE 1995: Muller and Kirk's Small Animal Dermatology, $5^{\text {th }}$ ed., WB SAUNDERS, Philedelphia, pp. 882-883

SCOTT, DW, MILLER, WH, WELLINGTON, JR 1993: The combination of ormethroprim and sulfadimethoxine in the treatment of pyoderma due to Staphylococcus intermedius in dogs. Can Prac 18: 372-378

THORNSBERY, C, HILL, BC, SWENSON, JM, MCDOUGAL, LK 1983: Rifampin: spectrum of antibacterial activity. Rev Infect Dis 5: 412-417

WHITE, SD 1996: Systemic treatment of bacterial skin infections of dogs and cats. Vet Dermatol 7: 133-144

WHITTEM, T, GAON, D 1998: Principles of antimicrobial therapy. Veterinary Clinics of North America: Small Animal Practice 28: 197-213

WILSON, WD, SPENSLEY, MS, BAGGOT, JD, HIETALA, SK 1988: Pharmacokinetics, bioavailability and invitro antibacterial activity of rifampicin in horse. Am J Vet Res 49: 2041 -2046 